\title{
Okul Yöneticisi ve Öğretmenlerin Koronavirüs Salgını İle İlgili Görüşleri, Sürecin Tutum ve Davranışlarına Etkileri ve Uzaktan Ĕgitim Alg1larının İncelenmesi
}

\begin{abstract}
Salih AKYILDIZ ${ }^{1}$ ve Ergün YURTBAKAN²
Öz

Bu çalışma okul yöneticisi ve öğretmenlerin koronavirüs salgını ile ilgili görüşleri, izolasyon sürecinin tutum ve davranışlarına etkisi ve uzaktan eğitim algılarının incelenmesi amacıyla yapılmıştır. Tarama yöntemine başvurulan araştırmaya, küme örnekleme yolu ile seçilen toplam 662 ögretmen ve okul yöneticisi dahil edilmiştir. Anket yardımı ile toplanan veriler SPSS ve Excel programı ile analiz edilmiş ve tablolar halinde sunulmuştur. Araştırma sonucunda; koronavirüs salgını ile ilgili okul yöneticilerinin ve öğretmenlerin salgının Çin'den yayılan tehlikeli bir virüs görüşünde oldukları, virüsün Allah'ın insanlara bir uyarısı olduğunu düşündükleri, dünyadaki yaşlı nüfusun azaltılması için tasarlanmadığını düşündükleri ve diğer salgınlardan farklı ve çok abartılmadığı görüşünde oldukları belirlenmiştir. Okul yöneticilerinin ve öğretmenlerin covid-19 salgını ile ilgili haberlerde yetkili olmayanları dinlemedikleri fakat yetkililere de güvenmedikleri, salgın ile ilgili haberleri izleyince kısmen korkup panikledikleri ve tedbirler alarak tevekkül ettikleri ortaya çıkmıştır. İzolasyon sürecinde okul yöneticilerinin ve öğretmenlerin kitap okuma, TV izleme, uyuma, çocuklarının derslerine yardımcı olma gibi davranışlar sergiledikleri; kısmen müzik dinledikleri, kendilerini geliştirici çalışmalara zaman ayırdıkları tespit edilmiştir. Okul yöneticilerinin ve öğretmenlerin Covid-19 salgın sürecinde yapılan uzaktan eğitimin yüz yüze eğitime göre öğrencileri motive etmede, ögrencileri derse aktif katmada, öğretmenlerin derste materyal kullanmalarında, ölçme ve değerlendirme faaliyetlerinin güvenirliğinde yetersiz olduğu, öğrencilere iyi bir öğrenme firsatı sağlamadığı ve yüz yüze eğitime alternatif olamayacağı görüşünde oldukları ortaya çıkmıştır.
\end{abstract}

Anabtar Kelimeler: Koronaviriüs, Covid-19, İzolasyon, Uzaktan eğitim, Öğretmen, Okul yöneticisi.

The Views of School Administrators and Teachers about the Coronavirus Outbreak, the Effects of the Process on Attitudes and Behaviors, and Investigation of Distance Education Perceptions

\begin{abstract}
This study was conducted to examine the views of school administrators and teachers about the coronavirus epidemic, the effect of the isolation process on their attitudes and behaviors, and their perceptions of distance education. A total of 662 teachers and school administrators selected by cluster sampling were included in the research, in which the survey method was applied. The data collected with the help of the questionnaire were analyzed with SPSS and Excel software and presented in tables. As a result of the research, it has been determined that school administrators and teachers regarding the coronavirus epidemic are of the opinion that the epidemic is a dangerous virus spreading from China, that they think it is a warning from God, that they do not consider it to have been be designed for reducing the elderly population and that it is different from other epidemics and is not exaggerated. It is revealed that school administrators and teachers do not pay attention to unauthorized people on the news about the Covid-19 epidemic but they also don't trust the authorized people, they are partially scared and panicked when they watch the news about the epidemic and take precautions and trust the process. It is determined that during the lockdown the school administrators and teachers exhibited behaviors such as reading, watching TV, sleeping, helping their children with their homework, sometimes listening to music and spending time for their personal development. It is revealed that school administrators and teachers have been insufficient in motivating the students during the Covid-19 distance education, having students participate the lessons actively, teachers' material usage in the lessons, having the reliability of measurement and evaluation activities compared to the face-to-face education and that distance education cannot be an alternative to face-to-face education.
\end{abstract}

Key Words: Coronavirus, Covid-19, Isolation, Distance Education, Teacher, School Administrator

\section{Atıf İçin / Please Cite As:}

Akyıldız, S. ve Yurtbakan, E. (2021). Okul yöneticisi ve öğretmenlerin koronavirüs salgını ile ilgili görüşleri, sürecin tutum ve davranışlarına etkileri ve uzaktan eğitim algılarının incelenmesi. Manas Sosyal Araştırmalar Dergisi, 10(4), 2191-2203.

Geliş Tarihi / Received Date: 28.12.2020

Kabul Tarihi / Accepted Date: 08.08.2021

\footnotetext{
${ }^{1}$ Doç. Dr. - Türkiye-Trabzon Üniversitesi Eğitim Fakültesi, sakyildiz61@gmail.com

iD ORCID: 0000-0002-8569-7411

2 Öğretmen - Türkiye-Trabzon Faruk Başaran Bilim Sanat Merkezi, gamsiz6436@gmail.com

(iD) ORCID: 0000-0001-8811-6320
} 


\section{Giriş}

Aralık 2019'un sonlarında, Çin'in Wuhan bölgesinde koronavirüs (COVID-19) salgını başlamış ve hızla dünyanın diğer bölgelerine yayılmıştır. Dünyada daha önce de bu tür krizler yaşamıştır. 2000 yılından bu yana, ciddi akut solunum sendromu (SARS), domuz gribi, Orta Doğu solunum sendromu (MERS) ve Ebola, küresel sistemleri test etmiş, ama hiç biri COVID-19'un yaptığ1 gibi dünya ekonomisini felç etmemiş ve sosyal ilişkileri bu boyutta etkilememiştir (OECD, 2020, s. 1). Diğer yandan, COVID-19'un SARS-CoV ve MERS-CoV gibi koronavirüs ailelerine göre daha düşük bir ölüm oranına sahip olduğu görülmüştür (Chen, 2020, s. 1; Xu vd., 2020, s. 420). Ancak yüksek bulaşma oranına sahip olması ve aşısının olmaması nedeniyle, virüsün yayılımının kontrolünde ciddi zorluklar yaşanmıştır (Xu vd., 2020, s. 420). Salgın ulusal sınırları aşmış, milliyeti, eğitim düzeyi, geliri veya cinsiyeti ne olursa olsun bütün insanları etkilemiştir (Schleicher, 2020). Hastalık bu nedenle dünya sağlık örgütü tarafından küresel salgın olarak ilan etmiştir.

Koronavirüs salgının yayılmaya başlamasıyla birlikte ülkeler sağlıkta ekonomide kamuda ve sosyal yaşamda bir dizi önlem paketleri açıllamaya başlamıştır. İlk etapta kitlesel hareketliliği önlemek için önce sınırlar kapatılmış, iç ve dış hat uçuşları durdurulmuş ve şehirlerarası ulaşım kısıtlanmıştır. Çalışma hayatına yönelik tedbirler alınmıştır. İnsanların bir araya gelmesini gerektiren her organizasyon ya iptal edilmiş ya da ileri bir tarihe ertelenmiştir. Bireysel olarak virüsten korunma yolları konusunda medyadan bilgilendirmeler yapılmıştır. Sağlık hizmetlerinin sunumunda radikal değişikliklere gidilmiş, yeni kararlar hızla uygulamaya sokulmuştur. Hastalığın yayılmasını en aza indirebilmek için evden çıkmama, maske takma zorunluluğu, sosyal mesafenin korunması, seyahat kısıtlaması gibi birçok önlem alınmıştır. Diğer çalışanlar gibi öğretmenler de bu süre içinde evde izole edilmişlerdir.

Salgının en önemli etkilerinden biri de eğitim sistemleri üzerinde olmuştur. Yüz yüze eğitime ara verilmesi koronavirüsün yayılmasını kontrol altına almaya yönelik tedbirler arasında yer almıştır. Çocuklar tıbbi açıdan risk altındaki bir kategori olmasa da, koronavirüs salgınından önemli ölçüde etkilenmiştir (OECD, 2020, s. 2). UNESCO (2020), 17 Mayls 2020 tarihi itibariyle, dünya nüfusunun\% 69,3'ünü oluşturan yaklaşık 1,21 milyar öğrencinin bu durumdan etkilendiğini belirtmiştir. İzolasyon önlemlerinin yüz yüze eğitimi aksatacağına, bu dönemde öğrenme fırsatını korumak için etkili bir strateji bulunmadığ1 takdirde öğrencilerde ciddi öğrenme kayıplarına neden olacağına dikkat çekilmiştir (Reimers ve Schleicher, 2020). Koronavirüs salgını, dünya genelinde çocukların sağlı̆̆ına, sosyal ve maddi refahına zarar vermiş, evsiz çocuklar ve yoksul çocuklara en ağır darbeye maruz kalmıstır. Bunun yanında okul kapanışları, sosyal alanlardan uzaklaşma, çocuklar arasında yetersiz beslenme, aile içi şiddete maruz kalma, kaygı ve stresi artırma riskini arttırmışıı (OECD, 2020, s. 2). UNESCO (2020), okulların kapanması karşısında okulların ve öğretmenlerin öğrencilere uzaktan ulaşmak ve eğitimin aksamasını sınırlamak için kullanabileceği açı eğitim uygulamaları ve platformlanının kullanılmasını önermiştir.

Bütün dünyada olduğu gibi ülkemizde de ilk vakaların görülmesinden itibaren virüsün yayılımını engellemek için hükümet tarafindan önleyici tedbirler alınmış, hastalığın yayılmasını engellemek için yüz yüze eğitime ara verilmiş ve 23 Mart'ta evde uzaktan eğitim sistemine geçilmiştir. Uzaktan eğitim süreci Milli Eğitim Bakanlığ1 tarafından, Eğitim Bilişim Ağ1 (EBA) web sitesi (www.eba.gov.tr) ve televizyon (TRT EBA TV İlkokul, TRT EBA TV Ortaokul, TRT EBA TV Lise) aracillğıyla yürütülmüștür. Dersler ilkokul ve ortaokullarda 09.00-14.00 saatleri arasında öğrencilere sunulmuş, derslerin tekrarları 14.30-19.30 saatleri arasında yapılmıştır. Liselerde dersler 09.00-16.00 saatleri arasında veriliş, ders tekrarları ise 16.30 ile 23.30 saatleri arasında yapılmıştır (Özer, 2020, s. 3). Okulların planlaması ile öğretmenler bu sürece eğitim bilişim ağı üzerinden zaman zaman senkronik derslerle katılarak destek vermiştir.

Eğitim, e-öğrenmenin ayırt edici yükselişi ile birlikte eğitim, uzaktan ve dijital platformlarda öğretimin yapıldığı dramatik bir şekle dönüşmüştür (Li ve Lalani, 2020). Uzaktan eğitim, salgın döneminde, eğitimin devam ettirilebilmesi için vazgeçilmez bir eğitim uygulaması olmuş, bununla birlikte uzaktan eğitimin popülaritesi artmıştır. Okul yöneticileri, öğretmenler, öğrenciler ve veliler uzaktan eğitim uygulamaları ile tanışmış ve kısa sürede yoğun bir deneyimleme süreci yaşanmıştır. Hatta veliler ve öğretmenlerin uzaktan eğitimin her öğretmenin kendi öğrencileri ile yüz yüze canlı ders şeklinde devam etmesini önermiştir (Yurtbakan ve Akyıldız, 2020). Dünyada dil uygulamaları, sanal özel ders, video konferans araçları veya çevrimiçi öğrenme yazılımlarının kullanımında salgından bu yana önemli bir artış olmuştur (Li ve Lalani, 2020). 
Her ne kadar hükümetlerin çoğunluğu sürekli eğitim firsatları sağlamak için önemli çaba sarf etse de, kaliteli öğrenme kapasiteleri- özellikle dezavantajlı nüfus için - büyük ölçüde değişmektedir (Vegas, 2020). Çoğu ülke bu kadar büyük çaptaki uzaktan eğitime hazırlıksız yakalanmıştır. Ülkelerdeki uzaktan eğitime erișmedeki sosyo-ekonomik farklılıklar ne yazık ki eğitimde firsat eșitliğini engellemiștir. Dünyada düşük gelir düzeyindeki ülkelerin ancak yüzde 25 'inden azı şu anda her türlü uzaktan öğrenmeyi sağlamaktadır ve bunların çoğunluğu uzaktan eğitime erişmek için TV ve radyo kullanmaktadır. Buna karşılık, yüksek gelirli ülkelerin yüzde 90'a yakını çevrimiçi olarak sağlanan uzaktan öğrenme firsatları ögrencilere sunmaktadır (Vegas, 2020). Okullar açıkken, hemen hemen tüm ülkede farklı sosyo-ekonomik geçmişe sahip ailelerin çocukları arasındaki akademik başarı farklılıklarının, özellikle okulların kapanmasıyla, Covid-19 salgını nedeniyle derinleşeceğinden endişe duyulmaktadır.

İzolasyon döneminde öğretmenler ve öğrenciler çeşitli dijital araçlar kullanmak zorunda kalmışlardır. Bu süreç içinde birçoğunun uzaktan eğitim uygulamaları ile ilgili bilgi ve becerilerinin geliştiği söylenebilir. Diğer yandan koronavirüs nedeniyle yaşanan izolasyon sürecinin, ortaya çıan haberlerin öğretmenlerin görüşleri, tutumları ve algıları üzerinde önemli etkilerinin olduğu tahmin edilmektedir. Bu bakımdan ögretmen ve öğrencilerin uzaktan eğitim uygulamaları ile ilgili yargılarının ortaya çıkarılması, uzaktan eğitim uygulamasının değerlendirilmesi ve gelecekte alınacak kararlara yol gösterici olması bakımından önemlidir. Ayrıca bu araştırmada ortaya çıkacak bulgular, müfredatın düzenlenmesi, teknoloji destekli öğrenme modellerinin ögrenme ortamlarında yer bulması bakımından da önemlidir. Salgının insan psikolojisi ve kitleler üzerindeki büyük etkilerinin olacağı, salgın sorasında bu etkilerin uzun zaman devam edebileceği tahmin edilmektedir. Sosyal hayatımız üzerinde bu kadar kapsamlı ve derin etkileri olan salgının hayatımızdaki muhtemel etkilerinin neler olabileceği ile ilgili çok yönlü araştırmaların yapılması gerekmektedir.

Literatürde Covid-19'un sağllk, ekonomi, sosyal ve sosyoekonomik alanına etkisini inceleyen çalışmaların yapıldığı görülmektedir (Ankaralı, 2020, s. 59; Chen, 2020, s. 69; Dal Canbazoğlu, 2020, s. 356; Kay1ş, 2020, s. 65; Khosravi, 2020; Prem vd., 2020; Uludağ, 2020, s. 118, Wang vd., 2020, s. 1; Xiao, 2020, s. 175). Eğitim alanında ise yapılan çalışmalanın Covid-19'un eğitime etkisi ve izolasyon döneminde uygulanan uzaktan eğitim uygulamaları hakkında öğrenci, veli, öğretmenlerin ve yöneticilerin görüşlerinin incelendiği görülmektedir (Arora ve Srinivasan, 2020, s. 43; Bakioğlu ve Çevik, 2020, s. 109; Bayburtlu, 2020, s. 131; Carrillo ve Flores, 2020, s. 466; Duban ve Şen, 2020, s. 375; Karahan, Bozan ve Akçay, 2020, s. 201; Karakaya vd., 2021, s. 17; Külekçi Akyavuz ve Çakın, 2020, s. 723; Lee, Ward, Chang ve Downing, 2020; Mohalik ve Sahoo, 2020; Patricia, 2020, s. 1; Sar1 ve Nayır, 2020, s. 959; Sirem ve Baş, 2020, s. 993; Taşar, 2021, s. 171; Viner vd., 2020, s. 397; Yang, 2020, s. 1; Yurtbakan ve Akyıldız, 2020, s. 949). Ayrıca Covid-19'un üniversite öğrencilerinin sosyal yaşamlarına etkisinin de araştırldığı görülmektedir (Bennett, Uink ve Cross, 2020) Fakat salgının öğretmenler ve okul yöneticilerinin algıları üzerinde ne tür etkiler bıraktığının araştırılmadığı görülmektedir. Bunun yanında Covid-19'un insanların psikolojik durumlarına etkilerinin araştırıldığı çalışmalar olsa da (Bozdağ, 2020, s. 249; Cullen, Gulati ve Kelly, 2020, s. 1; Stankovska, Memedi ve Dimitrovski, 2020, s. 33) izolasyon sürecinin sadece akademisyenler, sağllk çalışanları ve kadınların tutum ve davranışlanı üzerinde nasıl etki bıraktığının araştırıldığı görülse de (Ceyhan ve Uzuntarla, 2020, s. 261; Demir ve Toprak, 2020, s. 393; Guanche Garcell, 2020) okul yöneticilerinin ve öğretmenlerin tutum ve davranışları üzerinde nasıl bir etki yarattı̆̆ının araştırılmadığı görülmektedir. Bu nedenle de okul yöneticileri ve öğretmenlerin koronavirüs salgını ile ilgili görüşlerinin, izolasyon sürecinin tutum ve davranışlarına etkisinin ve uzaktan eğitim algılarının incelenmesinin araştırmaya değer olduğu saptanmıştır. Bu bağlamda araştırmada "okul yöneticileri ve öğretmenlerin koronavirüs salgını ile ilgili görüşlerinin, izolasyon sürecinin tutum ve davranışlarına etkisinin ve uzaktan eğitim algılarının incelenmesi” amaçlanmışır. Bu amaç kapsamında şu sorulara cevap aranmıştır.

1. Koronavirüs salgını ile ilgili okul yöneticisi ve öğretmenlerin görüşleri nelerdir?

2. Koronavirüs salgını ilgili haberlerin okul yöneticisi ve öğretmenlerin tutum ve davranışlarına etkileri nelerdir?

3. Koronavirüs salgını nedeniyle yaşadığımız izolasyon sürecinin yönetici ve öğretmenlerin tutum ve davranışlarına etkileri nelerdir?

4. Yönetici ve öğretmenlerin uzaktan eğitim algıları nelerdir? 


\section{Yöntem}

$\mathrm{Bu}$ araştırma, nicel araştırma yaklaşımı içerisinde tarama modeline dayalı bir çalışmadır. Tarama (survey) modeli, bir kütlenin eğilimlerinin, tutumlarının ve görüşlerinin nicel bir açıklamasını veya bu kütlenin bir örneğini inceleyerek bir kütlenin değişkenleri arasındaki ilişkilendirmeleri test eder (Creswell ve Creswell 2018). Tarama modelleri; "geçmişte ya da halen var olan bir durumu var olduğu şekliyle betimlemeyi amaçlayan araştırma yaklaşımıdır. Araştırmacı olay ya da durumu olduğu gibi yansıtmaya çalışı" (Karasar, 2009, s.77).

\section{Evren - Örneklem}

Araştırmanın evreni, 2020-2021 eğitim-öğretim ylında, Trabzon İli Ortahisar ilçe merkez sınırları içinde yer alan ilkokul, ortaokul ve liselerde çalışan, yaklaşı 4200 öğretmenden oluşmaktadır. Evren ölçülen değişkeni etkileme potansiyeli olmayan alt evrenlerden oluştuğu için araştırmanın örneklemi bu okullardan olasıllğı bilinen örnekleme türlerinden küme örneklem yöntemiyle belirlenmiştir. Küme örneklemesi, tüm popülasyonun kümelere veya gruplara ayrllmasıdır. Örneklem bu kümelerden rastgele seçilerek alınır (Wilson, 2014, s. 227). Küme örnekleme yönteminde hem kümeler, hem de kümelerden alınan alt kümeler seçkisiz yolla seçilir (Erkuş, 2011, s. 105). Buna göre, ilkokul, ortaokul ve liseler birer küme kabul edilmiş ve bu kümelerin her birinden seçkisiz yolla alt kümeler belirlenmiştir. Alt kümelerde yer alan tüm okul yöneticileri ve öğretmenler araştırmaya dahil edilmiştir. Araştırmaya toplam 662 öğretmen katılmıştır. Örneklemi oluşturan öğretmenlerin \% 50,6's1 kadın (347 kişi), \% 49,4’ü erkek (339) öğretmenden oluşmaktadır.

Bilimsel çalışmalarda \%95 güven aralığında $\mathrm{N}=5.000$ kişilik hedef kitle için gerekli örneklem büyüklüğü 357 olarak kabul edilmektedir (Baş, 2005, s. 47). Buna göre bu çalışmada 4200 kişilik hedef kitle için 662 kişilik örneklem büyüklüğünün oldukça yeterli olduğu söylenebilir. Örneklemi oluşturan öğretmen adaylarının değiş̧kenlere göre dağılımı ise Tablo 1'de verilmiştir.

Tablo 1. Örneklem Grubunun Ceşitli Öæelliklere Göre Dağ̆lhm

\begin{tabular}{|c|c|c|c|c|c|c|c|}
\hline Değişkenler & Kategoriler & $\mathbf{N}$ & $\%$ & Değişkenler & Kategoriler & $\mathbf{N}$ & $\%$ \\
\hline \multirow{2}{*}{ 1. Cinsiyet } & Kadın & 347 & 50,6 & \multirow{4}{*}{$\begin{array}{l}\text { Branş } \\
\text { (devam..) }\end{array}$} & Resim & 17 & 2,6 \\
\hline & Erkek & 339 & 49,4 & & Beden Eğitimi & 15 & 2,3 \\
\hline \multirow{15}{*}{ 2. Branş } & Sınıf Öğretmeni & 254 & 38,4 & & Rehberlik & 19 & 2,9 \\
\hline & Okul Öncesi Öğretmeni & 28 & 4,2 & & Diğer. & 29 & 4,4 \\
\hline & Matematik (Lise) & 20 & 3,0 & \multirow{2}{*}{ 3. Görev } & Yönetici & 84 & 12,7 \\
\hline & Matematik (Ortaokul) & 23 & 3,5 & & Öğretmen & 578 & 87,3 \\
\hline & Biyoloji-Kimya & 16 & 2,4 & \multirow{3}{*}{ 4. Görev Yeri } & İlkokul & 321 & 48,5 \\
\hline & Tarih-Coğrafya & 20 & 3,0 & & Ortaokul & 189 & 28,5 \\
\hline & Türk Dili ve Edebiyatı & 20 & 3,0 & & Lise & 152 & 23,0 \\
\hline & İngilizce & 43 & 6,5 & \multirow{8}{*}{ 5. Kıdem } & $1-5 \mathrm{y} 1 \mathrm{l}$ & 22 & 3,3 \\
\hline & Sosyal Bilgiler & 23 & 3,5 & & $6-10 \mathrm{yil}$ & 65 & 9,8 \\
\hline & Türkçe & 24 & 3,6 & & $11-15 \mathrm{yll}$ & 86 & 13,0 \\
\hline & Fizik & 15 & 2,3 & & $16-20 \mathrm{yll}$ & 125 & 18,9 \\
\hline & Fen Bilgisi & 24 & 3,6 & & $21-25$ y1l & 161 & 24,3 \\
\hline & Din Kültürü ve Ahlak Bilgisi & 57 & 8,6 & & $26-30 \mathrm{yil}$ & 95 & 14,4 \\
\hline & İmam Hatip Meslek Dersleri & 15 & 2,3 & & 31 y1l ve üstü & 108 & 16,3 \\
\hline & & & & & Genel Toplam & 662 & 100.0 \\
\hline
\end{tabular}

\section{Veri Toplama Araçları}

Anket. Veriler araştırmacı tarafindan geliştirilen anket yoluyla toplanmıştır. Anket, tarama yönteminde sıklıkla kullanılan bir veri toplama aracıdır (Ekiz, 2009, s. 115). Anket (sormaca) hem hazırlanmasinin kolay olması hem de çok sayıda bireye ulaşmak için sosyal bilimlerde özellikle tarama amacıyla kullanılmaktadır. Ölçekten farklı olan anket, kişilerin birçok özelliği ile ilgili bilgi toplamak için kullanılan bir araç olduğu için bir toplam puandan ve dolayısıyla ölçeklerdeki gibi teknik anlamda geçerlik ve güvenirlikten söz etmek mümkün değildir (Erkuş, 2011, s. 144). Bu nedenle güvenirlik hesaplaması yapılmamış olup anket geliştirirken bazı aşamalardan geçilmiştir. Öncelikle ankette bulunan koronavirüs salgını ile ilgili görüş maddeleri, TV programlarında düzenlenen sağlık, ekonomi, siyaset alanındaki uzmanların katıldığı tartışma programlarının yanında literatür taraması sonucu; izolasyon sürecindeki tutum ile davranışlara etkisi ve 
uzaktan eğitim algıları ile ilgili maddeler de benzer çalısmalar incelenerek ve literatür taraması yapılarak hazırlanmıştır. Sonra toplam 33 sorudan oluşan anket sosyal bilimler, sağlık bilimleri, Türkçe eğitimi, uzaktan eğitim ve ölçme ve değerlendirme alanlarında uzman olan birer akademisyenin görüşüne sunulmuş ve onayları alınmıştır. Daha sonra 10 sınıf öğretmenine pilot olarak uygulanarak ankete son hali verilmiştir. Anket, demografik veriler ve öğretmenlerin görüss, tutum ve alg1lar1 olmak üzere iki bölümden oluşmaktadır. Anketin ikinci bölümü, öğretmenlerin koronavirüs salgını ile ilgili görüşleri, salgın ile ilgili haberlerin öğretmenlerin tutum ve davranışlanna etkisi, öğretmenlerin izolasyon döneminde geçirdikleri zamana etkisi ve öğretmenlerin uzaktan eğitim algiları ile ilgili 33 sorudan oluşmuştur. Koronavirürüs salgını nedeniyle bir izolasyon süreci yaşandığı için anketin geleneksel yöntemlerle katılımcılara ulaştırılması ve anketin geri toplanması çok zor olacağı için "modern" olarak tanımlanan teknolojik yollar tercih edilmiştir. Bu amaçla anket, "Google formlar” üzerinden düzenlenmiş ve anket formunun linki doğrudan katılımcıların mail adreslerine ve okullar bünyesinde oluşturulan whatsapp gruplarına gönderilmiştir. Hız ve maliyet açısından avantajlı olması, sanal ortamda kolay doldurulabilmesi, analiz açısından kolaylıklar sağlaması nedeniyle bu yöntem tercih edilmiştir.

\section{Verilerin Analizi}

Anket verileri SPSS ve Excel programları kullanılarak analiz edilmiştir. Yapılan analiz sonuçları tablo ve grafikler olarak düzenlenmiştir.

\section{Bulgular}

Araştırmada okul yöneticisi ve öğretmenlerin covid-19 salgını ile ilgili görüşleri, izolasyon sürecinin tutum ve davranışlarına etkisi ve uzaktan eğitim algılarının incelenmesi amaçlanmıştır. Bu amaçla okul yönetici ve öğretmenlerden toplanan veriler grafiklerle gösterilmiş ve açıklanmıstır.

\section{Koronavirüs Salgını İle İlgili Okul Yöneticileri ve Öğretmenlerin Görüşleri}

Okul yöneticileri ve öğretmenlerin koronavirüs salgını ile ilgili görüşlere katıllım düzeyleri grafik 1'de gösterilmiştir.

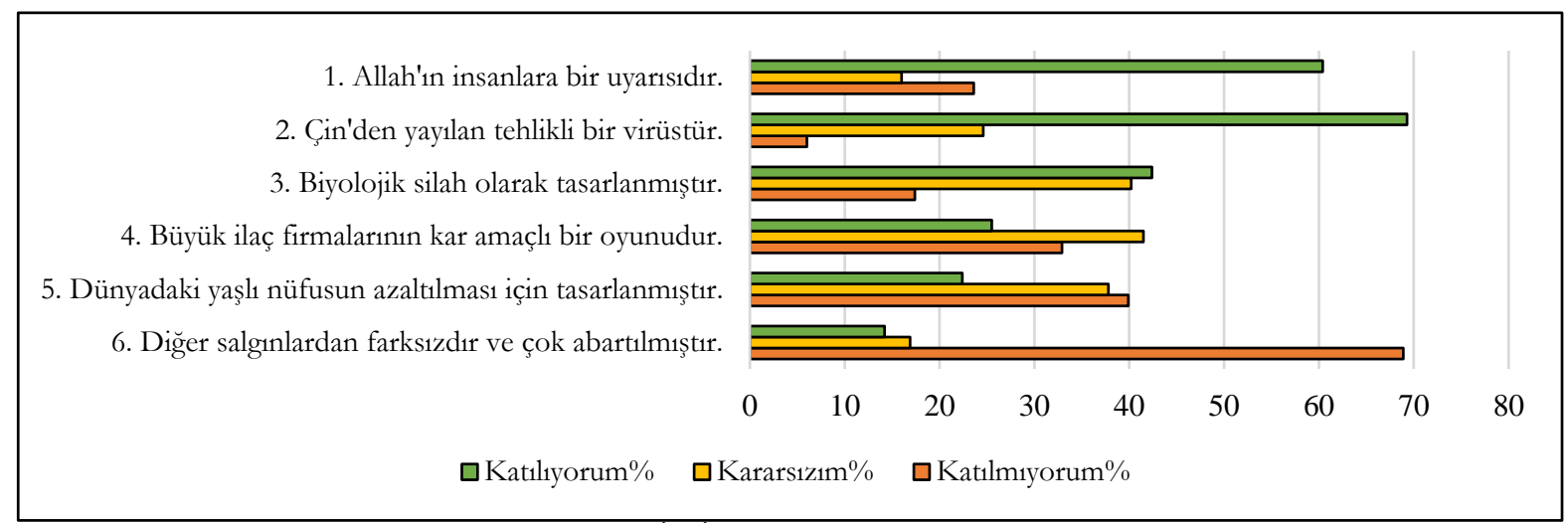

\section{Şekil 1. Koronavirüs Salgm İle Illgili Okul Yöneticileri ve Ögretmenlerin Görüsleri}

Şekil 1 incelendiğinde, okul yöneticileri ve öğretmenlerin, koronavirüs “Allab’in nyarısıdr»" görüşüne yarıdan fazlasının \%60,4'ünün ( $\mathrm{N}=400)$ katıldığ1, “Cin'den yaynlan teblikeli bir virüstür" görüşüne \%69,3'ünün $(\mathrm{N}=459)$ katıldığı anlaşılmıştır. Yönetici ve öğretmenlerin, koronavirüs "biyolojik silah olarak tasarlanmıștı" ifadesine \%42,4'ünün ( $\mathrm{N}=281)$ katıldığı, \%40,2'sinin ( $\mathrm{N}=266)$ kararsız kaldığı, \%17,4'ünün $(\mathrm{N}=115)$ katılmadığı; "büyüle ilas firmalarmm kar amaģh bir oyunudur" ifadesine \% 25,5'inin ( $\mathrm{N}=169)$ katıldığı, \%41,5'inin (N=275) kararsız kaldığı, \%32,9'unun ( $\mathrm{N}=218)$ katılmadığ anlaşılmıştır. Okul yöneticisi ve öğretmenler "dünyadaki yaşl nüfusun az̧altılması için tasarlanmıştır" ifadesiyle ilgili yönetici ve öğretmenler arasında bir görüsş birliğinin oluşmadığ \%39,9'unun (N=264) katılmadığ1, \%37,8’inin kararsız kaldığ1 $(\mathrm{N}=250)$ ve \%22'sinin katıldığ $(\mathrm{N}=148)$ görülmüştür. Yönetici ve öğretmenler, "diğer salgzinlardan farksız̨dr ve çok abartılmıştır” görüşüne ise çoğunlukla $(\% 68,9)$ katılmadıkları $(\mathrm{N}=456)$ anlaşılmışır. 


\section{Koronavirüs Salgını İle İlgili Haberlerin Okul Yöneticileri ve Öğretmenlerin Tutum ve Davranışlarına Etkileri}

Salgınla ilgili haberlerin okul yöneticileri ve öğretmenlerin tutum ve davranışlarına etkileri ile ilgili görüşleri Şekil 2'de sunulmuştur.

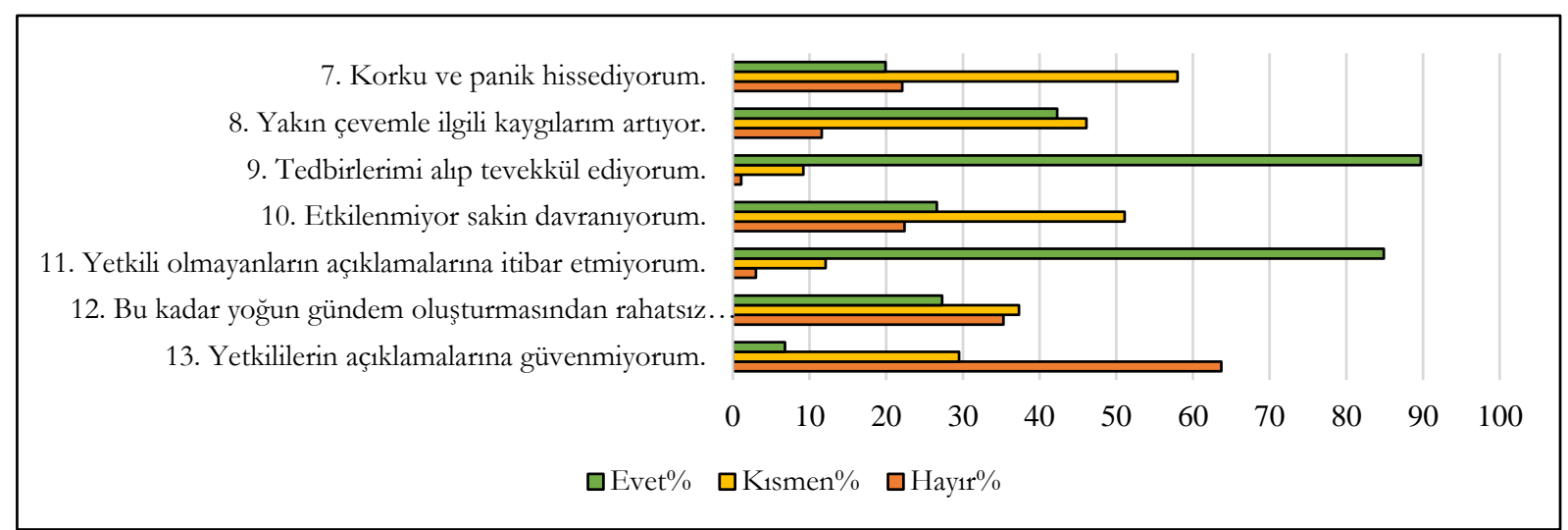

Şekil 2. Koronavirüs Salgm İle İlgili Haberlerin Okul Yöneticisi ve Ögretmenlerin Tutum ve Davramş̧larna Etkisi

Şekil 2'ye göre, yönetici ve öğretmenlerin salginla ilgili haberlere yönelik olarak \%58'inin ( $N=384)$ kısmen korku ve panik hissettiğini, \%22,1'inin (N=146) korku ve panik hissetmediğini, \%19,9'unun $(\mathrm{N}=132)$ ise korku ve panik hissettiğini kabul etmiştir. Yönetici ve öğretmenlerin \%42,3’ünün $(\mathrm{N}=280)$ yakın çevresiyle kaygılandıkları, \%46,1'inin ( $\mathrm{N}=305)$ yakın çevresiyle kısmen kaygılandıkları, \%11'inin $(\mathrm{N}=77)$ ise kaygilanmadıkları anlaşılmaktadır. Yönetici ve öğretmenlerin çok büyük bir kısmı \%89,7 $(\mathrm{N}=594)$ salgınla ilgili haberler karşısında tedbir alıp tevekkül ettiklerini ifade etmiştir. Haberler karşısında yönetici ve ögrretmenlerin \%51'inin (N=338) kısmen sakin davrandığ1, \%26,6'sının ( $N=176)$ sakin davrandığı, \%22,4'ünün (N=148) ise sakin davranmadığı anlaşılmaktadır.

\section{İzolasyonun Okul Yöneticileri ve Öğretmenlerin Tutum Ve Davranışlarına Etkileri}

Salgın döneminde yaşanan izolasyon sürecinin okul yöneticileri ve öğretmenlerin tutum ve davranışlarına etkileri ile ilgili durumlar Şekil 3’te verilmiştir.

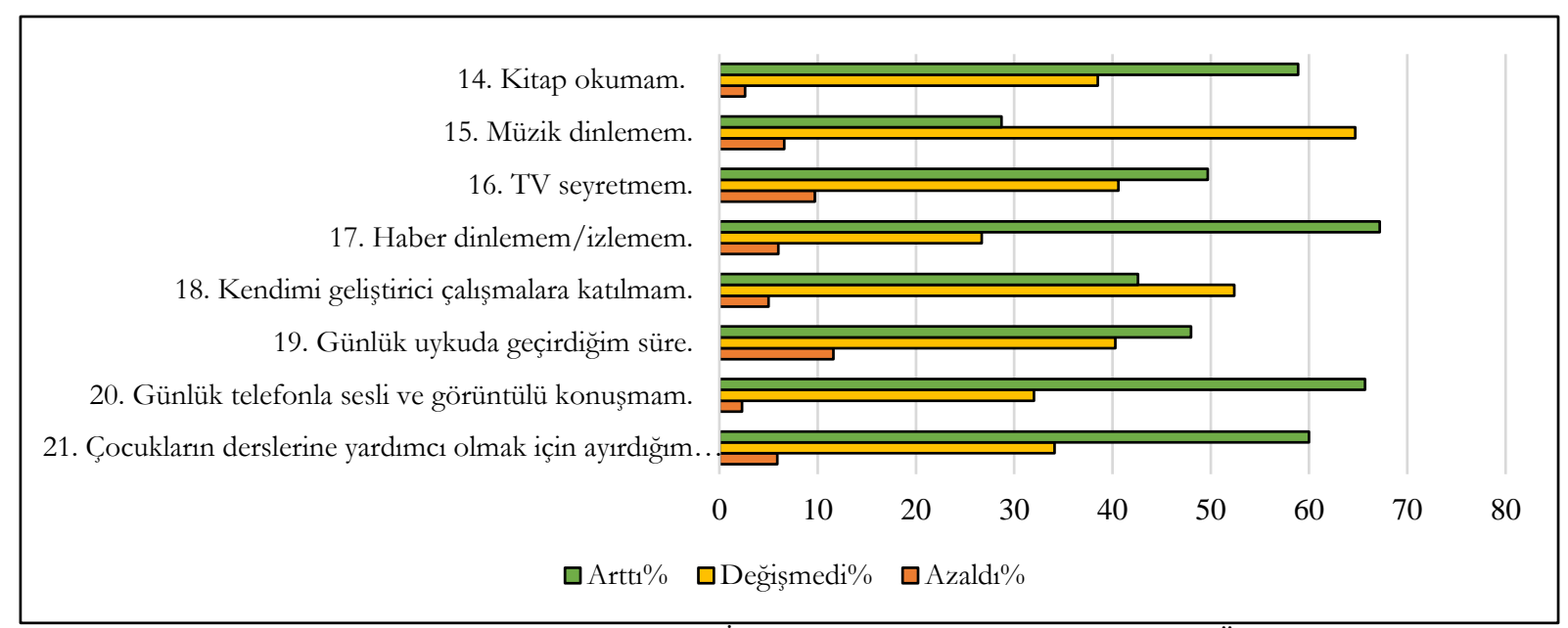

Şekil 3. Koronavirüs Salgm Döneminde Yaşanan İzolasyon Sürecinin Okul Yöneticisi ve Ögrretmenlerin Tutum ve Davranıslarna Etkisi

Şekil 3 incelendiğinde, izolasyon döneminde yönetici ve öğretmenlerin çoğunluğunun \%58,9 (N=390) kitap okumalarının arttı̆̆ı, bir kısmının ise değişmediği \%38,5 (N=255); müzik dinleme etkinliklerinin çoğunlukla değişmediği \% 64,7 ( N=428), bir kısmının ise arttığ1 \%28,7 (N=190) görülmektedir. Yönetici ve öğretmenlerin hemen yarısının \%49,7 (N=329) daha fazla TV izledikleri, belli bir kısmında TV izleme oranının değişmediği \%40,6 (N=269); çoğunluğunun ise \%67,2 (N=445) haber dinleme ve izlemelerinin arttığı anlaşılmaktadır. İzolasyon döneminde yönetici ve öğretmenlerin yarıdan fazlasının \%52,4 (N=347) 
kendilerini geliștirecek bir faaliyete katılma durumlarını değişmediği, yarıya yakın bir kısmının \%42,6 $(\mathrm{N}=282)$ ise kendilerini geliştirecek faaliyetlerinin arttığı; yönetici ve öğretmenlerin yarıya yakınının \%48 $(\mathrm{N}=318)$ uykuda geçen sürelerinin arttı̆̆1, bir kısmında bu sürenin değişmediği \%40,3 ( $=267)$ ortaya çıkmıştır. Yönetici ve öğretmenlerin izolasyon sürecinde çok büyük kısmının \%65,7 (N=435) telefonu daha çok kullandığı; bu dönemde çoğunlukla \%60 (N=397) çocukların derslerine yardımcı olmak için zaman ayırdıkları tespit edilmiştir.

\section{Okul Yöneticileri ve Öğretmenlerin Uzaktan Eğitim Algıları}

Okul yöneticileri ve öğretmenlerin izolasyon sürecinde uygulanan uzaktan eğitim ile ilgili algıları şekil 4’te sunulmuştur.

22. UE, yüz yüze eğitime göre daha etkilidir.

23. UE, ögrencileri ders takip etmede yeterince motive etmez.

24. UE'de materyal tekrar tekrar izlenebildiğinden öğrenci için avantajlıdır.

25. UE'de materyal tekrarlı kullanılabildiği için orta vadede öğretmene ihtiyaç azalır.

26. UE, avantajlar sunsa da yüz yüze eğitimden daha iyi bir alternatif olamaz.

27. UE'de yapılan ölçme ve değerlendirme faaliyetlerinin güvenirliği düşüktür.

28. UE, uygulamaları açısından öğrenciyi daha aktif hale getirir.

29. UE, öğrenciler için iyi bir öğrenme fırsatı sağlar.

30. UE, öğrenmenin kalıcı olmasını sağlar.

31. UE'de başarı daha çok öğrencinin başarısına bağlıdır.

32. UE, geleneksel eğitimden daha etkilidir.

33. Öğretimin en iyi şekilde gerçekleşmesi için yüz yüze etkileşim gereklidir.

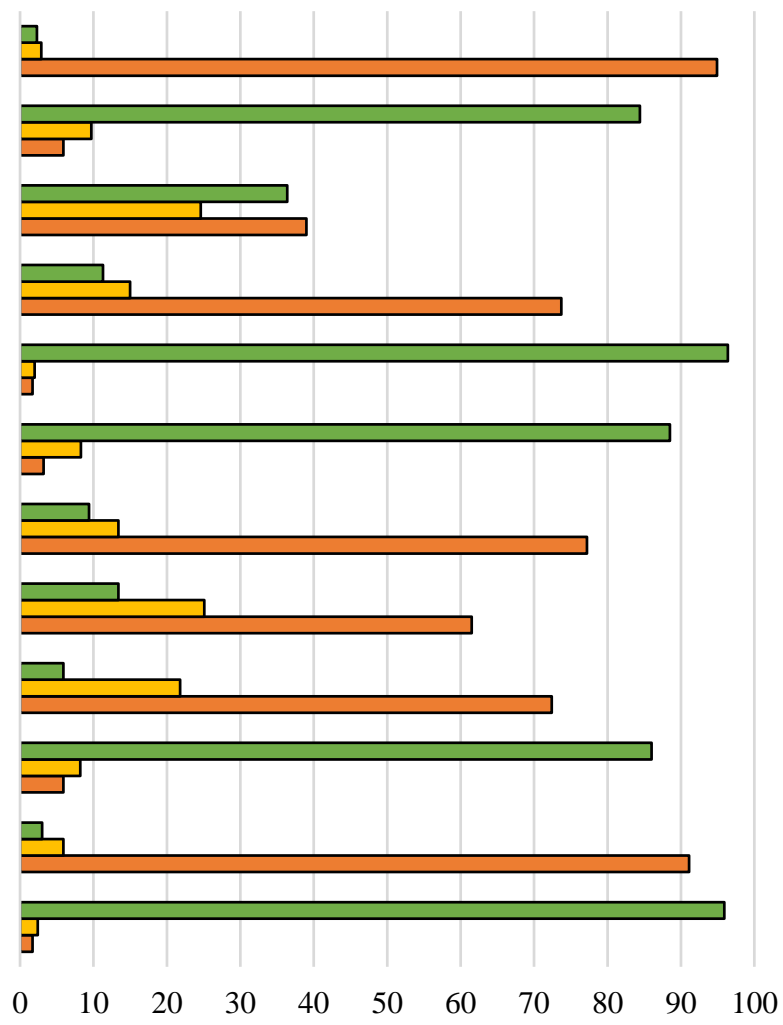

$\square$ Katıllyorum $\% \quad$ 口Kararsızım $\% \quad$ 口Katılmiyorum $\%$

Şekil 4. Okul Yöneticisi ve Öğretmenlerin Uzaktan Ë̆itim (UE) Algisı

Şekil 4'teki verilere göre, okul yöneticileri ve öğretmenlerin tamamına yakınının \%94,9 ( $N=628)$

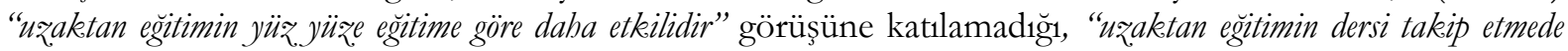
yeterince motive etme" görüşüne çok büyük oranda \%84,4 (N=559) katıldıkları görülmektedir. Katıllımcıların, "uzaktan eğitimde materyal tekrar tekrar iə̌lenebildiğinden ögrrenciler için avantajlddr" ifadesiyle ilgili bir görüș birliği içinde olmadıkları (\%36,4'ünü (N=241) katıldığ1, \%39'unun (N=258) katılmadı̆̆ı, \%24,6'sının (N=163) kararsız kaldığı anlaşılmaktadır. Yönetici ve öğretmenler, "uح̧aktan eğitimde materyal tekrarl kullanulabildiği için orta vadede ögretmene ibtiyas aح̧alır" görüşüne büyük oranda \%73,7 (N=488) katıldığ1, "u₹aktan eğitim avantajlar sunsa da yüz yüze eğitimden daba iyi bir alternatif olamą" görüşüne katılımciların hemen hemen tamamının \%96,4 (N=638) katıldığ1, yine "u₹aktan eğitimde ölçme ve değerlendirme faaliyetlerinin güvenirliğ̈ düsükttür" görüşüne hemen tamamının \%88,5 (N=586) katıldığı görülmektedir.

Yönetici ve öğretmenlerin "u₹aktan eğitim uygulamalar açısindan ögrrenciyi daba aktif hale getirir" görüşüne büyük oranda \%73,7 (N=488) katılmadıkları, benzer biçimde "u₹aktan eğitim öğrenciler için iyi bir öğrenme firsatı sağlar" görüşüne çoğunluğunun \%61,5 (N=407) katılmadı̆̆1 ve "uzaktan eğitimin ögrrenmenin kahcı olmasim sağlar" görüşüne büyük çoğunluğunun \%72,4 (N=479) katılmadığ anlaşılmaktadır. Okul yöneticisi ve öğretmenlerin, "u₹aktan eğitimde başar daha çok ögrencinin çabasına bağhldır" görüşüne çok büyük oranda \%86 
(N=569) katıldığı, "uzaktan eğitim geleneksel eğitimden daha etkilidir" görüşüne ise hemen hepsinin \%91,1 (N=603) katılmadığ1 gözlenmiştir. Yönetici ve ögretmenler "öğretimin en iyi şsekilde gerçeklessmesi için yüz. yüze etkileşim gereklidir" görüşüne hemen hepsi \% 95,9 (N=635) katılmışlardır.

\section{Tartışma, Sonuç ve Öneriler}

Okul yöneticilerinin ve öğretmenlerin koronavirüs salgını ile ilgili görüşleri, izolasyon sürecinin tutum ve davranışlarına etkisi ve uzaktan eğitim algılarının incelenmesi amacıyla yapılan çalışmanın sonunda; koronavirüs salgını ile ilgili okul yöneticilerinin ve öğretmenlerin salgının Çin'den yayılan tehlikeli bir virüs görüşünde oldukları, virüsün Allah'in insanlara bir uyarısı olduğunu düşündükleri, dünyadaki yaşlı nüfusun azaltılması için tasarlanmadığını düşündükleri ve diğer salgınlardan farklı ve çok abartılmadığı görüşünde oldukları belirlenmiştir. Okul yöneticilerinin ve öğretmenlerin covid-19 salgını ile ilgili haberlerde yetkili olmayanları dinlemedikleri fakat yetkililere de güvenmedikleri, salgin ile ilgili haberleri izleyince kısmen korkup panikledikleri ve tedbirler alarak tevekkül ettikleri ortaya çıkmıştır. İzolasyon sürecinde okul yöneticilerinin ve öğretmenlerin kitap okuma, TV izleme, uyuma, çocuklarının derslerine yardımcı olma gibi davranışlar sergiledikleri; kısmen müzik dinledikleri, kendilerini geliştirici çalışmalara zaman ayırdıkları tespit edilmiştir. Okul yöneticilerinin ve öğretmenlerin Covid-19 salgın sürecinde yapılan uzaktan eğitimin yüz yüze eğitime göre öğrencileri motive etmede, öğrencileri derse aktif katmada, ögretmenlerin derste materyal kullanmalarında, ölçme ve değerlendirme faaliyetlerinin güvenirliğinde yetersiz olduğu, ögrencilere iyi bir öğrenme firsatı sağlamadığ1 ve yüz yüze eğitime alternatif olamayacağ1 görüşünde oldukları ortaya çıkmıştır.

Araştırmada ise okul yöneticileri ve öğretmenlerin koronavirüs salgınının Çin'den yayılan tehlikeli bir virüs olduğu, Allah'ın insanlara bir uyarısı olduğu, yaşlı nüfusu azaltmak için yapilan bir çalışma olmadığı ve diğer virüslerden farklı olmasının yanında çok abartılmadığı fikrinde oldukları ortaya çıkmıştır. Yetişkin bireyler üzerinde yapılan bir çalışmada da yetişkinlerin salgının Allah'n insanlara bir uyarısı olarak algıladıkları, virüse karşı tedbirler alıp tevekkül ettikleri, daha sağlıklı ve düzenli beslendikleri ortaya çıkmıştır (Demir ve Toprak, 2020, s. 401, 402, 403). Toplumun hangi sinıfinda olursa olsun insanların salginı Allah'ın insanlara bir uyarısı olarak algilamasının ve tedbirler alıp tevekkül etmelerinin altında dini inançları yatıyor olabilir. Salgının Çin'den yayılan bir virüs olduğu görüşünde olmalarının nedeni ise ulusal ve uluslararası basında Dünya Sağlık Örgütü gibi resmi kurum yöneticileri, ülkelerin sağlık alanındaki bilim insanları tarafından Covid-19'un pandemi olarak tanımlaması olabilir. Hatta bu sebeple okul yöneticileri ve öğretmenler virüsün dünyadaki yaşlı nüfusun azaltılması için tasarlanmadığı ve diğer salgınlardan farklı olduğu ve abartılmadığı görüşünde olabilirler. Fakat okul yöneticileri ve öğretmenler virüsün biyolojik silah olarak tasarlandığı, kısmen de olsa büyük ilaç firmalarının kar amaçlı bir oyunu olduğu görüşünde olmalarının nedeni ise haber programlarında Covid-19'un nasıl çıktığ ile ilgili farklı görüsslerin tartışılması yatıyor olabilir. Çünkü insanlar ideolojilerine yakın olan insanların, geçmişte yaşanan insan hayatını olumsuz etkileyen konular hakkında öngörüde bulunmuş ve hakllı̆̆ı ortaya çıkmış kişilerin düşüncelerine önem verebilirler.

Okul yöneticilerinin ve öğretmenlerin covid-19 salgını ile ilgili haberlerde yetkili olmayanları dinlemedikleri fakat yetkililere de güvenmedikleri ortaya çıkmıștır. Covid-19 virüsünün yeni olması ve sürekli mutasyona uğruyor olması, yapılan bilimsel araştırmalarda virüsle ilgili farklı sonuçlara ulaşılması uzmanların düşüncelerinin değişmesine neden oluyor olabilir. İnsanları virüs hakkında aydınlatmak için TV programlarına çıkan bu uzmanların farklılaşan düşünceleri okul yöneticilerinin ve öğretmenlerin yetkililere olan güvenlerini olumsuz etkiliyor olabilir. Salgınla ilgili izlenen haberler insanların korkmasına neden olmaktadır (Dal Canbazoğlu, 2020, s. 356). Her ne kadar eğitim düzeyi yüksek olan insanlar Covid-19'a karşı gerekli tedbirleri almaları nedeniyle kendilerini güvende hissedip psikolojik sorunlar yaşanmadı̆̆1 görülse de (Bozdağ, 2020, s. 249), araştırmadaki okul yöneticilerin ve öğretmenlerin korkma, panikleme gibi psikolojik sorunlar yaşadığ1 tespit edilmiştir. Yapılan bazı araştırmalarda Covid-19'un korku, depresyon, yalnızlık, duygusal sıkıntı, sosyal işlev gibi psikolojik sorunlara da yol açtığı görülmektedir (Cullen, Gulati ve Kelly, 2020, s. 1; Lee, Ward, Chang ve Downing, 2020; Stankovska, Memedi ve Dimitrovski, 2020, s. 33; Wang vd., 2020, s. 1; Xiao, 2020, s. 175). Salginın psikolojik sorunlara yol açmasının nedeni, salgının henüz önüne geçilmiş olamaması ve vaka sayılarının sürekli değiş̧kenlik göstermesi olabilir.

Okul yöneticilerinin ve öğretmenlerin izolasyon döneminde kitap okumadı̆̆ı, haber dinlemediği, telefonla konuşmadığı ortaya çıkarken çocuklarının derslerine yardımcı olma, uyuma gibi davranışlar sergiledikleri, kısmen de olsa kendilerini geliştirici çalışmalara katıldığı ortaya çımıştır. Okul müdürlerinin 
salgın döneminde zamanlarını büyük oranda "internet", "kişisel bakım ve temizlik" ve "sosyal medya" türü etkinliklerle geçirdikleri (Taşar, 2021, s. 171), öğretmenlerin ise mesleki gelişimlerine katkı sağlayıcı uzaktan eğitim hizmet içi kurslara katıldığı görülmektedir (Yurtbakan ve Akyıldız, 2020, s. 964). Yapılan başka bir araştırmada ise yetişkinlerin salgın döneminde kitap okuma, TV izleme ve müzik dinleme, uyuma gibi faaliyetler sergiledikleri ortaya çıkmıştır (Demir ve Toprak, 2020, s. 404). Oysa yeni koronavirüse yakalanma kaygısı uyumayı erteletmektedir (Kıraç vd., 2021, s. 495). Salgın döneminde insan etkileşimini azaltmak için alınan tam kapanma gibi kararların yanında insanların birbirlerine virüsü bulaştırmak istenmemesi izolasyon döneminde insanların bireysel hobiler yapmaya yönelttiğgi düşünülebilir. $\mathrm{Bu}$ hobilerin de bireylerin ilgi, yetenek, ihtiyaç ve eğitim düzeylerinden etkilendiği düşünülebilir.

Araştırmada okul yöneticilerin ve öğretmenlerin yüz yüze eğitimin uzaktan eğitime göre öğrencileri motive etmede, materyal kullanmada, ölçme değerlendirme faaliyetlerinin güvenilirliğinde, öğrencilere öğrenme firsatı sağlamada, öğrenilenlerin kalıcılığında ve öğrenci başarısında daha etkili olduğu görüşünde oldukları ortaya çıkmıştır. Okul yöneticilerinin, öğretmenlerin ve öğrencilerin bu görüşte olmalarının sebebi; internet bağlantılarında teknik aksaklıklar yaşanması, uzaktan eğitimde ders sürelerinin az olması, öğrencilerle etkileşim kurulamaması, materyal ve öğrenci merkezli yöntem teknikler kullanılamaması ve dersin değerlendirilmesinin zor olması gibi etkenler olabilir. Çünkü Covid-19 izolasyon döneminde yapılan öğretmen, okul yöneticisi ve öğrencilerle uzaktan eğitimle ilgili yapılan görüşmelerde; süre yetersizliği, bağlantı sorunu gibi teknik yetersizlikler, öğrencilerin derse katılımı ve öğrencilerle olan etkileşim ve iletişim eksikliği, konuların yüzeysel anlatılması nedeniyle öğrenmenin güçleşmesi gibi sorunlar yaşandığ1 ortaya çıkmıştır (Bayburtlu, 2020, s. 131; Karahan, Bozan ve Akçay, 2020, s. 201; Külekçi-Akyavuz ve Çakın, 2020, s. 723; Mohalik ve Sahoo, 2020, Sar1 ve Nayir, 2020, s. 959; Yurtbakan ve Akyıldız, 2020, s. 966). Bu sorunlar öğrencilerin yüz yüze eğitimi uzaktan eğitime tercih etme (Patricia, 2020, s. 1) nedeni de olabilir. Ayrıca Covid-19 döneminde yapılan uzaktan eğitim; evinde internet, bilgisayar olmayan öğrenciler için firsat eşitsizliğine de neden olmaktadır (Bennett, Uink ve Cross, 2020; Carrillo ve Flores, 2020, s. 466). Fakat Covid-19 döneminde yapılan uzaktan eğitimin okuma güçlüğü yaşayan ilkokul öğrencilerine fayda sağladığı görülmektedir (Sirem ve Baş, 2020). Araştırmada ise okul yöneticilerinin ve öğretmenlerin uzaktan eğitimin başarısının öğrenci başarısına bağlı olduğu görüşünde oldukları tespit edilmiştir. $\mathrm{Bu}$ bağlamda uzaktan eğitimin hem gelişim geriliği yaşayan hem de normal gelişim gösteren başarılı öğrenciler üzerinde etkili olduğu düşünülebilir. Bunun nedeni ise gelişim geriliği yaşayan öğrencilerle yapılan uzaktan eğitim faaliyetlerinde öğrenci sayısının az olması, öğretmen ve öğrenci arasındaki etkileşimi artırıyor, gelişim geriliği yaşayan öğrencinin derse daha aktif katılımını sağlıyor olabilir. Covid-19 döneminde uzaktan eğitimde yaşanan iletişim eksikliği öğrenci başarısını olumsuz etkilemektedir (Arora ve Srinivasan, 2020, s. 43). Normal gelişim gösteren başarılı ögrencilerin ise soyut düşünme becerilerinin gelişmiş olması, derse hazırlıklı gelme, derste öğrendiklerini tekrar etme gibi davranışlar sergilemeleri uzaktan eğitim faaliyetlerinin amacına ulaşmasında etkili oluyor olabilir.

Çalışmaya yönelik yapılan öneriler şunlardır:

1. Okul yöneticileri ve öğretmenlerin Covid-19 salgını hakkında yanlış düşüncelere kapılmamaları adına, alanında uzman kişiler tarafından kamu spotları hazırlanabilir.

2. Salgın döneminde eve kapanan, toplu olarak yapılabilen sosyal aktivitelerden uzaklaşan okul yöneticileri ve öğretmenlerin yaşadıkları korku, panik, kaygı gibi psikolojik sorunları aşmaları için TV'lerde yayınlanan haber ve tartışma programlarında salgının neden olduğu ölüm sayısı, artan vaka sayıları yerine salgın ile ilgili olumlu gelişmelere daha fazla yer verilebilir.

3. İzolasyon döneminde eve kapanan okul yöneticileri ve öğretmenlerin evde sağllklı ve faydalı zaman geçirebilmeleri için TV'ler aracıllŏı ile el sanatlarını geliştirme (ahşap, seramik boyama), yağlı boya resim yapma, zekâ oyunları gibi yeni hobiler edinmelerini sağlayacak yayınlar yapılabilir.

4. Okul yöneticileri ve öğretmenleri okullarındaki bilgisayar, internet bağlantısı sorunu olan öğrencileri tespit ederek, öğrencilerin eksikliklerini gidermek için gerekli devlet kurumlarından ve yardım kuruluşlarından yardım isteyebilir.

5. Öğretmenler, uzaktan eğitim derslerin daha verimli geçmesi ve öğrencilerin kalıcı öğrenmeler gerçekleştirmesi için ders esnasında öğrencileri sürece aktif katacak etkinlikler düzenleyebilir.

6. Öğretmenler, öğrencilerin evlerinde bulunan atık malzemelerden (kâğıt, karton, ip, odun parçası) faydalanarak konu ile ilgili somut materyal hazırlamalarına ayrı bir ders saati ayırarak materyal hazırlamalarına yardımcı olabilirler. Bu sayede soyut olan konular somutlaştırlabilir ve kalıcı öğrenmeler sağlanabilir. 
7. İleriye yönelik olarak öğretmenlerin uzaktan eğitimde hangi derslerin öğretiminde sorunlar yaşadığını tespit edecek çalışmalar yapılabilir.

\section{Etik Beyan}

"Okul Yöneticisi ve Öğretmenlerin Koronavirüs Salgm ile İlgili Görüsleri, Sürecin Tutum ve Davranıslarnna Etkileri ve Uz̧aktan Eğitim Algzlarmın İncelenmesi” başıklı çalışmanın yazım sürecinde bilimsel kurallara, etik ve alıntı kurallarına uyulmuş; toplanan veriler üzerinde herhangi bir tahrifat yapılmamış ve bu çalışma herhangi başka bir akademik yayın ortamına değerlendirme için gönderilmemiştir. Gerekli olan etik kurul izinleri Trabzon Üniversitesi Sosyal ve Beşeri Bilimler Bilimsel Araştırma ve Yayın Etik Kurulu'nun 18.11.2020 tarihli toplantısında alınmıştır.

\section{Kaynakça}

Ankaralı, H. (2020). Türkiye'de COVID-19 salgın sürecinde ihtiyaç duyulacak yoğun bakım yatak ve solunum cihazı sayilarınin direkt tahmini. Anatolian Clinic the Journal of Medical Sciences, 25 (Supplement 1), 59-62. http://dx.doi.org/10.21673/anadoluklin.715628.

Arora, A. K. ve Srinivasan, R. (2020). Impact of pandemic COVID-19 on the teaching-learning process: A study of higher education teachers. Prabandhan: Indian Journal of Management, 13(4), 43-56.

Bakioğlu, B. ve Çevik, M. (2020). COVID-19 pandemisi sürecinde fen bilimleri öğretmenlerinin uzaktan eğitime ilişkin görüssleri. Turkish Studies, 15(4), 109-129. https://dx.doi.org/10.7827/TurkishStudies.43502

Baş, T. (2005). Anket nasl hą̧rlantr uygulant değerlendirilir? Ankara: Seçkin.

Bayburtlu, Y. S. (2020). Covid-19 pandemi dönemi uzaktan eğitim sürecinde öğretmen görüşlerine göre Türkçe eğitimi. Turkish Studies, 15(4), 131-151. https://dx.doi.org/10.7827/TurkishStudies.44460

Bennett R., Uink B. ve Cross S. (2020). Beyond the social: Cumulative implications of COVID-19 for first nations university students in Australia. Social Sciences \& Humanities Open, 2(1). doi: https://doi.org/10.1016/j.ssaho.2020.100083

Bozdağ, F. (2020). Pandemi sürecinde psikolojik sağlamlık. Turkish Studies, 15(6), 247-257. https://dx.doi.org/10.7827/TurkishStudies. 44890

Carrillo, C. ve Flores, M. A., (2020). COVID-19 and teacher education: A literature review of online teaching and learning practices. European Journal of Teacher Education, 43(4), 466-487. doi: 10.1080/02619768.2020.1821184

Ceyhan, S. ve Uzuntarla, Y. (2020). Akademik personelin COVID-19'a yönelik bilgi, tutum ve davranışlarının belirlenmesi. Turkish Studies, 15(6), 259-276. https://dx.doi.org/10.7827/TurkishStudies.45988

Chen, J. (2020). Pathogenicity and transmissibility of 2019-nCoV-a quick overview and comparison with other emerging viruses. Microbes and infection, 22(2), 69-71.

Creswell, J. W.ve Creswell, J. D. (2018). Research design. Qualitative, quantitative, and mixed methods approaches. Fifth Edition.

Cullen, W., Gulati, G., \& Kelly, B.D. (2020). Mental health in the Covid-19 pandemic. QJM: An International Journal of Medicine, hcaa110, 1-4. https://doi.org/10.1093/qjmed/hcaa110

Dal Canbazoğlu, A. (2020). Türkiye'de Covid-19 Yeni Koronavirüs hastalığı vakasının ortaya çıktı̆̆ ve yayılmaya başladığı ilk günlerde yayınlanan kamu spotu ve reklamların izleyici üzerindeki etkisi. Turkish Studies, 15(6), 351 389. https://dx.doi.org/10.7827/TurkishStudies.43904

Demir. Z. ve Toprak, A. Ö. (2020). Covid-19 Salgını nedeniyle yaşanan karantina günlerinde kadınların virüs ve gündelik yaşamla ilgili tutum ve davranışları. Turkish Studies, 15(6), 391-413. https://dx.doi.org/10.7827/TurkishStudies.45139

Duban, N. ve Şen, F. G. (2020). Sınıf öğretmeni adaylarının COVID-19 pandemi sürecine ilişkin görüşleri. Turkish Studies, 15(4), 357-376. https://dx.doi.org/10.7827/TurkishStudies.43653.

Erkuş, A. (2011). Davramış bilimleri için bilimsel araștırma süreci. Ankara: Seçkin.

Ekiz, D. (2009). Bilimsel arastrma yöntemleri. Anı Yayıncilik, Ankara.

Guanche Garcell, H. (2020). COVID-19. A Challenge for Healthcare Professionals. Revista Habanera de Ciencias Médicas,19(2): e_3284_E.

Karahan, E., Bozan, M. A. ve Akçay, A. O. (2020). Sınıf öğretmenliği lisans öğrencilerinin pandemi sürecindeki çevrim içi öğrenme deneyimlerinin incelenmesi. Turkish Studies, 15(4), 201-214. https://dx.doi.org/10.7827/TurkishStudies.44348

Karakaya, F., Adıgüzel, M., Üçüncü, G., Çimen, O. ve Yılmaz, M. (2021). Teachers' views towards the effects of Covid-19 pandemic in the education process in Turkey. Participatory Educational Research, 8(2), 17-30. doi. 10.17275/per.21.27.8.2

Karasar, N. (2009). Bilimsel arastruma teknikleri. Nobel Yayınları, Ankara.

Kayış, F. (2020). Koronavirüs (covid-19) salgınının konut ve çatılı işyerleri kiralarına etkileri üzerine düşünceler. Avrasya Sosyal ve Ekonomi Arastrmalar Dergisi, 7(4), 65-84.

Khosravi, M. (2020). Perceived Risk of COVID-19 pandemic: The role of public worry and trust. Electronic Journal of General Medicene.,17(4), em203. https://doi.org/10.29333/ejgm/7856. 
Kıraç, R., Söyler, S., Yılmaz, G. ve Uyar, S. (2021). Effect of the anxiety to catch coronavirus (COVID-19) on bedtime procrastination. Cukurova Medical Journal, 46, 495-507.

Külekçi Akyavuz, E. ve Çakın, M. (2020). Covid-19 salgınının eğitime etkisi konusunda okul yöneticilerinin görüşleri. Turkish Studies, 15(4), 723-737. https://dx.doi.org/10.7827/TurkishStudies.44140

Lee, S. J., Ward, K.P., Chang, O.D. ve Downing, K.M. (2020). Parenting activities and the transition to home-based education during the Covid-19 pandemic. Children and Youth Services Review, 117. doi: https://doi.org/10.1016/j.childyouth.2020.105585

Li, C. ve Lalani, F. (2020). The COVID-19 pandemic has changed education forever. This is how. World Economic Forum (Erişim: https://www.weforum.org/agenda/2020/04/coronavirus-education-global-covid19-onlinedigital-learning/ adresinden 14. Mayıs 2020 tarihinde alınmıştır.

Mohalik, R. ve Sahoo, S. (2020). E-Readiness and perception of student teachers' towards online learning in the midst of COVID-19 pandemic. http://dx.doi.org/10.2139/ssrn.3666914

OECD, (2020). What role might the social outcomes of education play during the COVID-19 lockdown? (Erişim: http://www.oecd.org/education/what-role-might-the-social-outcomes-of-education-play-during-the-covid-19lockdown-8aa53421-en.htm adresinden 15.05.2020 tarihinde alınmıştır.

Özer, M. (2020). Educational policy actions by the ministry of national education in the times of COVID-19. Kastamonu Education Journal, XX(X), XXXX-XXXX. doi: 10.24106/kefdergi.722280

Patricia, A. (2020). College students' use and acceptance of emergency online learning due to COVID-19. International Journal of Educational Research Open, 99(104), 1-33. doi: https://doi.org/10.1016/j.ijedro.2020.100011

Prem, K., Liu, Y., Russell, T. W., Kucharski, A. J., Eggo, R. M. ve Davies, N. (2020). The effect of control strategies to reduce social mixing on outcomes of the COVID-19 epidemic in Wuhan, China: a modelling study. The Lancet Public Health, 5(5), E261-E270.

Reimers, F. M. ve Schleicher, A. (2020). A framework to guide an education response to the COVID-19 Pandemic of 2020.

Sarı, T. ve Nayır, F. (2020). Pandemi dönemi eğitim: sorunlar ve firsatlar. Turkish Studies, 15(4), 959-975. https://dx.doi.org/10.7827/TurkishStudies.44335

Schleicher, (2020). How can teachers and school systems respond to the COVID-19 pandemic? Some lessons from TALIS. OECD. (Erişim: https://oecdedutoday.com/how-teachers-school-systems-respond-coronavirus-talis/ (erişim: 14. Mayıs 2020).

Sirem, Ö. ve Baş, Ö. (2020). Okuma güçlüğü olan ilkokul öğrencilerinin Covid-19 sürecinde uzaktan eğitim deneyimleri. Turkish Studies, 15(4), 993-1009. https://dx.doi.org/10.7827/TurkishStudies.43346

Stankovska, G., Memedi, I., ve Dimitrovski, D. (2020). Coronavırus COVID-19 disease, mental health and psychosocial support. Society Register, 4(2), 33-48. https://doi.org/10.14746/sr.2020.4.2.03

Taşar, H. H. (2021). Covid-19 pandemisi sürecinin okul müdürleri üzerindeki etkileri. Kırşehir Eğitim Fakültesi Dergisi, 22(1), 171-196

Uludağ, Ö. (2020). Koronavirüs enfeksiyonları ve yeni düşman: COVID-19. Adiyaman Üniversitesi Sağhlk Bilimleri Dergisi, 6(1), 118-127. https://dx.doi.org/10.30569/adiyamansaglik.716011.

UNESCO, (2020). COVID-19 Educational Disruption and Response. (erişim: https://en.unesco.org/covid19/education response (Erişim: 14.Mayıs 2020).

Vegas, E. (2020). School closures, government responses, and learning inequality around the world during COVID19 Erişim: https://www.brookings.edu/research/school-closures-government-responses-and-learninginequality-around-the-world-during-covid-19/ adresinden 18.05.2020 tarihinde alınmıştır.

Viner, R. M., Russell, S. J., Croker, H., Packer, J., Ward, J., Stansfield, C., Mytton, O., Bonell, C. ve Booy, R. (2020). School closure and management practices during coronavirus outbreaks including COVID-19: a rapid systematic review. Review, 4(5), 397-404.

Wang, Y., Wang, Y., Chen, Y. ve Qin, Q. (2020). Unique epidemiological and clinical features of the emerging 2019 novel coronavirus pneumonia (COVID-19) implicate special control measures. Journal of medical virology,1-9. https://doi.org/10.1002/jmv.25748

Wilson, J. (2014). Essentials of business research: A guide to doing your research project. Sage.

Xiao, C. (2020). A novel approach of consultation on 2019 novel coronavirus (COVID-19)- related psychological and mental problems: Structured letter therapy. Psychiatry investigation, 17(2), 175-176. https://doi.org/10.30773/pi.2020.0047

Xu, Z., Shi, L., Wang, Y., Zhang, J., Huang, L., Zhang, C., ... ve Tai, Y. (2020). Pathological findings of COVID-19 associated with acute respiratory distress syndrome. The Lancet respiratory medicine, 8(4), 420-422.

Yang, X. (2020). Teachers' perceptions of large-scale online teaching as an epidemic prevention and control strategy in China. ECNU Review of Education, 1-6. https:/ /dx.doi.org/ 10.1177/2096531120922244.

Yurtbakan, E. ve Akyıldız, S. (2020). Sınıf öğretmenleri, ilkokul öğrencileri ve ebeveynlerin covid-19 izolasyon döneminde uygulanan uzaktan eğitim faaliyetleri hakkındaki görüşleri. Turkish Studies, 15(6), 949-977. https://dx.doi.org/10.7827/TurkishStudies.43780 


\section{EXTENDED ABSTRACT}

In the literature, it is seen that studies examining the effect of Covid-19 on health, economy, social and socioeconomic areas have been conducted (Ankaralı, 2020, p. 59; Chen, 2020, p. 69; Dal Canbazoğlu, 2020, p. 356; Kayış, 2020, p. 65; Khosravi, 2020; Prem et all, 2020; Uludağ, 2020, p. 118, Wang et all, 2020, p. 1; Xiao, 2020, p. 175). In the field of education, it is seen that the opinions of students, parents and teachers about the effect of Covid-19 on education and the distance education practices applied during the isolation period are examined (Arora, \& Srinivasan, 2020, p. 43; Bakioğlu, \& Çevik, 2020, p. 109; Bayburtlu, 2020, p. 131; Carrillo, \& Flores, 2020, p. 466; Duban, \& Şen, 2020, p. 375; Karahan, Bozan, \& Akçay, 2020, p. 201; Karakaya et all, 2021, s. 17; Külekçi Akyavuz, \& Çakın, 2020, p. 723; Lee, Ward, Chang, \& Downing, 2020; Mohalik \& Sahoo, 2020; Patricia, 2020, p. 1; Sar1, \& Nay1r, 2020, p. 959; Sirem, \& Baş, 2020, p. 993; Taşar, 2021, p. 171; Viner et all, 2020, p. 397; Yang, 2020, p. 1; Yurtbakan, \& Akyldiz, 2020, p. 949). It is also seen that the effects of Covid-19 to university students' social lives have also been researched (Bennett, Uink, \& Cross, 2020). However, it is seen that the effects of the epidemic on the perceptions of teachers and school administrators have not been investigated. Moreover, even if there have been some studies on Covid-19's psychological effects on people (Bozdağ, 2020, p. 249; Cullen, Gulati, \& Kelly, 2020, p. 1; Stankovska, Memedi, \& Dimitrovski, 2020, p. 33) and some researches on isolation periods' effects on only the academicians', healthcare workers' and women's attitudes and behaviours (Ceyhan, \& Uzuntarla, 2020, p. 261; Demir, \& Toprak, 2020, p. 393; Guanche Garcell, 2020); it is seen that there hasn't been a study conducted on the effects of it on school administrators and teachers.

In this context, "the views of school administrators and teachers about the coronavirus epidemic, the effect of the isolation process on their attitudes and behaviors and the examination of their perceptions of distance education" was determined as the aim of the study. Within the scope of this purpose, the opinions of school administrators and teachers about the coronavirus epidemic, the effects of the news about the coronavirus epidemic on the attitudes and behaviors of school administrators and teachers, the effects of the isolation process we experienced due to the coronavirus epidemic on the attitudes and behaviors of administrators and teachers, and the perceptions of administrators and teachers on distance education have been searched for an answer.

This research is a study based on survey model in quantitative research approach. The population of the study was determined by the cluster sampling method of approximately 662 teachers out of approximately 4200 working in primary schools, secondary schools and high schools located within the boundaries of Trabzon Province Ortahisar district center in the 2020-2021 academic year. Data were collected by questionnaire. The questionnaire consists of two parts as demographic data and teachers' opinions, attitudes and perceptions. The second part of the questionnaire consists of 33 questions about teachers 'opinions about the coronavirus epidemic, the effect of the news about the epidemic on teachers' attitudes and behaviors, the effect of teachers' time spent in isolation, and teachers' perceptions of distance education. Survey data were analyzed using SPSS and Excel programs. The analysis results are arranged as tables and graphics.

In the study conducted to examine the views of school administrators and teachers about the coronavirus epidemic, the effect of the isolation process on their attitudes and behaviors, and their perceptions of distance education; it was revealed that school administrators and teachers were of the opinion that the coronavirus epidemic was a dangerous virus spreading in China. In the face of the news about the Covid-19 epidemic, it has been determined that school administrators and teachers exhibit attitudes and behaviors such as taking precautions, trusting in the process, and not listening to the news of the isolation process. It has been revealed that school administrators and teachers think that face-to-face education is more effective than distance education.

It has been revealed that it has been determined that school administrators and teachers related to the coronavirus epidemic are of the opinion that the epidemic is a dangerous virus spreading from China, that they think it is a warning from God, that they do not consider it to be designed for reducing the elderly population and that it is different from other epidemics and is not exaggerated. It is revealed that school administrators and teachers do not pay attention to unauthorized people on the news about the Covid-19 epidemic but they also don't trust the authorized people, they are partially scared and panicked when they watch the news about the epidemic and take precautions and trust the process. It is determined that school administrators and teachers show attitudes during the lockdown processes like reading, watching 
TV, sleeping, helping their kids with their homework, sometimes listening to music and spending time for their personal development. It is revealed that school administrators and teachers have been insufficient in motivating the students during the Covid-19 distance education, having students participate the lessons actively, teachers' material usage in the lessons, having the reliability of measurement and evaluation activities compared to the face-to-face education and that distance education cannot be an alternative to face-to-face education.

It was found in the study that school administrators and teachers think that face-to-face education is more effective than distance education. The reason why school administrators and teachers agree with this view may be technical problems, less lecture time, lack of interaction with students, and the difficulty of evaluating the course. Because in the studies conducted with teachers, school administrators and students about distance education during the Covid-19 isolation period, it is seen that problems occured such as technical deficiencies like lacking time, connection problems, students' participation in the course and lack of interaction and communication with students, and difficulties in learning due to the superficial teaching of the subjects (Bayburtlu, 2020, p. 131; Karahan, Bozan, \& Akçay, 2020, p. 201; Külekçi-Akyavuz, \& Çakın, 2020, p. 723; Mohalik, \& Sahoo, 2020, Sar1, \& Nayir, 2020, p. 959; Yurtbakan, \& Akyıldız, 2020, p. 966). These setbacks may be the reasons why students prefer face-to-face education (Patricia, 2020, p. 1). Besides, distance education during the pandemic has caused inequality of opportunity for those who do not have an access to internet or who do not have a computer at home (Bennett, Uink, \& Cross, 2020; Carrillo, \& Flores, 2020, p. 466). However, it is seen that distance education during the Covid-19 pandemic has been beneficial for primary school students who have reading difficulties (Sirem, \& Baş, 2020). In the study, it has been determined that school administrators and teachers are of the opinion that the success of distance education depends on student success. In this context, it can be thought that distance education is effective on successful students who have both developmental delay and normal development. The reason for that may be because there are less students in distance education activities which increases the interaction between teacher and student enabling students with developmental delay to participate more actively in the lesson. Lack of communication in distance education in Covid-19 period negatively affects student success (Arora, \& Srinivasan, 2020, p. 43). Distance education is effective in achieving its goal with successful students with normal development, on the other hand, because they have developed abstract thinking skills, or because of behaviours they have developed like being prepared for the lessons and repeating what they have learned previously. 